Technical note

Volumen 31(2):479-489. Mayo-agosto, 2020

e-ISSN 2215-3608, doi:10.15517/am.v31i2.39627

http://www.revistas.ucr.ac.cr/index.php/agromeso

\title{
White spot syndrome virus and Enterocytozoon hepatopenaei in shrimp farms in Costa Rica ${ }^{1}$
}

\section{Virus del síndrome de la mancha blanca y Enterocytozoon hepatopenaei en camarón de cultivo en Costa Rica}

\author{
Nelson Peña-Navarro ${ }^{2,3}$, Ruth Castro-Vásquez², Gaby Dolz ${ }^{2,4}$
}

1 Recepción: 10 de diciembre, 2019. Aceptación: 4 de marzo, 2020. This research was carried out with FIDA funds from the National University in the project entitled "Situación sanitaria del camarón blanco (Litopenaeus vannamei) en zonas productivas de Costa Rica".

2 Universidad Nacional (UNA), Posgrado Regional en Ciencias Veterinarias Tropicales (PCVET), Master's Degree in Tropical Diseases, Heredia, Costa Rica. bioruthi@gmail.com (https://orcid.org/0000-0002-2796-1536).

3 Universidad Tecnica Nacional, Research Directorate, Pacific Campus, Puntarenas, Costa Rica. npena@utn.ac.cr (corresponding author, https://orcid.org/0000-0002-8916-812X).

4 Universidad Nacional (UNA), Escuela de Medicina Veterinaria, Programa de Medicina Poblacional, Heredia, Costa Rica. gaby.dolz. wiedner@una.ac.cr (https://orcid.org/0000-0002-9566-5130).

\begin{abstract}
Introduction. The white spot syndrome virus (WSSV) causes systemic destruction of ectodermal and mesodermal tissues in shrimp and can cause $100 \%$ mortality. Enterocytozoon hepatopenaei (EHP) is an intracellular microsporidian that causes lysis of epithelial cells in hepatopancreatic tubules in shrimp. Objective. Detect the presence of WSSV and EHP in fifteen shrimp farms in the Gulf of Nicoya and the Central Pacific from Costa Rica. Materials and methods. Between January 2017 and July 2018 water during the filling process of the pond, postlarvae, and juvenile shrimp of Penaeus vannamei was collected, during a production cycle in each one of the fifteen farms. Samples were analyzed through polymerase chain reaction (PCR) using primers and protocols to detect the VP41B gene in WSSV, and the small subunit ribosomal RNA gene of EHP. Results. The presence of WSSV was detected in one farm, while EHP was not detected in any of the fifteen farms. The sequencing of the amplified segments of the VP41B gene showed $100 \%$ identity with isolated shrimp sequences in Taiwan and Mexico. Conclusion. WSSV was detected at a very low frequency and EHP was not detected in this study. It is necessary to continue monitoring these agents in the country's shrimp farms.
\end{abstract}

Keywords: Litopenaeus vannamei, virus, hepatopancreatic microsporidiosis, infectious disease, emerging disease.

\section{Resumen}

Introducción. El virus del síndrome de la mancha blanca (WSSV) causa la destrucción sistémica de los tejidos ectodérmicos y mesodérmicos en los camarones y puede causar una mortalidad del $100 \%$. El Enterocytozoon hepatopenaei (EHP) es un microsporidio intracelular que ocasiona lisis de las células epiteliales en los túbulos hepatopancreáticos del camarón. Objetivo. Detectar la presencia de WSSV y EHP en camarones de quince granjas 
ubicadas en el Golfo de Nicoya y el Pacífico Central de Costa Rica. Materiales y métodos. Entre enero 2017 y julio 2018 se recolectó agua durante el proceso de llenado del estanque, postlarvas y camarones juveniles de Penaeus vannamei, durante un ciclo productivo en cada una de las quince fincas. Las muestras se analizaron a través de reacción en cadena de la polimerasa (PCR), utilizando cebadores y protocolos para detectar el gen VP41B de WSSV y el gen de ARN ribosomal de la subunidad pequeña del EHP. Resultados. Se detectó la presencia de WSSV en una finca, mientras que no se detectó EHP en ninguna de las quince fincas. Las secuencias de los segmentos amplificados del gen VP41B mostraron una identidad del $100 \%$ con secuencias aisladas de camarón en Taiwán y en México.

Conclusión. Hubo baja frecuencia de WSSV, mientras que el EHP no fue detectado en este estudio. Es necesario continuar monitoreando estos agentes en las granjas camaroneras del país.

Palabras clave: Litopenaeus vannamei, virus, microsporidiosis hepatopancreática, enfermedad infecciosa, enfermedad emergente.

\section{Introduction}

The white spot syndrome virus (WSSV) belongs to the genus Whispovirus, family Nimaviridae (Lo et al., 2012), a double-stranded and enveloped DNA virus (Haq et al., 2012). The virus has a wide range of hosts, including crustaceans, mainly crabs, prawns and lobsters (OIE, 2018). Variants of WSSV are differentiated by their virulence, causing hyperacute, acute or chronic disease and mortality in penaeids (Bustillo et al., 2009) through systemic destruction of ectodermal and mesodermal tissues including gills, the cuticular epithelium, the antennal gland, lymphoid organ and hematopoietic tissue (Crockford, 2008), causing white spots or dots on the cephalotorax (Wu et al., 2001) and discoloration from pink to red (Crockford, 2008; OIE, 2018). To detect WSSV, histological examination, electron transmission microscopy, in situ hybridization techniques, polymerase chain reaction (PCR) techniques, and immunological detection methods were used, but PCR being the method of choice due to its high sensitivity, specificity and speed (Crockford, 2008; Haq et al., 2012; OIE, 2018). Multiple PCR protocols have been implemented for detecting WSSV, including one designed by Dhar et al. (2001) that amplifies the VP41B gene, which encodes for WSSV structural proteins. Biosecurity measures should be implemented to prevent the entry of WSSV into a farm, and if it is detected it is recommended to reduce stressors (sudden changes in temperature, salinity, and water oxygenation), as well as to implement cleaning and disinfection of ponds with chemical products, or to expose them to the sun (Sánchez-Paz, 2010). The virus was reported for the first time in Costa Rica in the year 2000 in shrimp production systems located in the Gulf of Nicoya, causing mortalities between $60 \%-70$ $\%$. Since 2008 it has been mandatory to report the presence of WSSV in shrimp farms (SENASA, 2010). In total, 98 cases of WSSV have been reported in Costa Rica, distributed as follows: 4 in 2006, in 2007 and 2010, 6 in 2011, 28 in 2012, 34 in 2013, 5 in 2014, 3 in 2015, and 10 in 2016 (SENASA, 2017).

Other pathogen that affect shrimp production is Enterocytozoon hepatopenaei (EHP), an intracellular microsporidian that causes the hepatopancreatic microsporidiosis (Aranguren et al., 2017). This agent replicates in the cytoplasm of epithelial cells of hepatopancreatic tubules in P. monodon and P. vannamei (Tourtip et al., 2009), causing lysis of these cells (Tang et al., 2017c). The main clinical signs include retarded growth, which causes variability in shrimp sizes, soft carapaces, lethargy, reduced feed intake and empty midguts (Aranguren et al., 2017). The parasite is diagnosed through histological examination, in situ hybridization techniques and PCR (Tangprasittipap et al., 2013; Tang et al., 2015). The PCR detection methods amplify the small ribosomal RNA subunit gene of EHP, called SSU rRNA (Aranguren et al., 2017; Tang et al., 2017b) and the spore protein gene 
(SWP) (Jaroenlak et al., 2016). Microsporidium has been reported in Asia (Tang et al., 2015; Rajendran et al., 2016; Shen et al., 2017) and recently in Venezuela (Tang et al., 2017a). There are no reports of EHP in Costa Rica.

Since 2000, when WSSV was first diagnosed in the country, only passive surveillance has been carried out by the authorities, that is, that diagnosis is only performed on farms where the presence of WSSV is suspected. Also, only few investigations of WSSV and none about EHP have been carried out in Costa Rica. The objective of this work was to detect the presence of WSSV and EHP in fifteen shrimp farms located in the Gulf of Nicoya and Central Pacific from Costa Rica.

\section{Materials and methods}

\section{Study area, type and design}

A non-systematic convenience, cross-sectional descriptive study was carried out. Fifteen farms were selected from a nationwide total of 89 (Carolina Elizondo, SENASA, personal communication, 2019), which met the following criteria for inclusion: 1 . little technified farms; 2 . only one production pond; and 3. low production due to mortality or decreased growth, since it was assumed that these were the farms in which there would be a higher probability of finding WSSV. The farms were located around the Gulf of Nicoya and the Central Pacific region from Costa Rica, and were visited twice: at the beginning of the production cycle (between January 2017 and June 2018), and 6-7 weeks after stocking, which is when the literature reports that the highest mortalities caused by WSSV occur in farms (Bustillo et al., 2009).

\section{Water and shrimp sampling}

During the first visit to the farm, on the day of stocking, a sample of $10 \mathrm{ml}$ of water was taken during the filling process of the pond, which was stored in vacutainer tubes. In addition, 100 postlarvae (day 0) were collected before stocking, which were stored in sterile tubes with $70 \%$ alcohol. During the second visit, 6-7 weeks after stocking, the farms were visited again, and five juvenile shrimp (5-10 g) were taken in the morning from three different places (at the point of entry of water, in the middle of the pond and at the point of drainage) with cast nets. These individuals had their hepatopancreas and stomach removed which were fixed in $70 \%$ alcohol. All samples were transported to the laboratory under refrigeration $\left(4-8{ }^{\circ} \mathrm{C}\right)$ and stored at $-80{ }^{\circ} \mathrm{C}$ until processing.

\section{Obtaining water physical-chemical parameters, geographical coordinates and data collection}

On the day in which juvenile shrimp were collected, the following water physicochemical parameters were obtained using a portable multiparameter water quality meter: temperature $\left({ }^{\circ} \mathrm{C}\right)$, dissolved oxygen $\left(\mathrm{mg} \mathrm{l}^{-1}\right), \mathrm{pH}$, and salinity (ppm). In addition, geographic coordinates were recorded for the four corners of each experimental pond using a global positioning system, and a precoded instrument was applied to each producer to obtain information about the general conditions of the farm, the production system, and sanitary management.

\section{Molecular techniques}

Water collected prior to stocking was centrifuged at $16,000 \times \mathrm{g}$ for $10 \mathrm{~min}$, the supernatant and the water precipitate, postlarvae, juvenile shrimp hepatopancreas, and stomachs were subjected to DNA extraction, which was performed using the DNeasy ${ }^{\circledR}$ Blood and Tissue kit (Qiagen), following the instructions provided by the 
manufacturer. The DNA extraction from hepatopancreas and stomach was preceded by the following extraction protocol published by Cardona et al. (2016). The aqueous phase was subjected to DNA extraction using the Dneasy ${ }^{\circledR}$ Blood and Tissue kit (Qiagen). Finally, the DNA concentration (ng $\left.\mu \mathrm{l}^{-1}\right)$ of each extracted sample was measured using a spectrophotometer (NanodropTM).

The samples (water, postlarvae, and juvenile shrimp hepatopancreas and stomachs) were analyzed using three PCR protocols (Table 1): in the first PCR the $\beta$-actin gene of the shrimp samples (postlarvae, hepatopancreas, and stomachs) was amplified according to the protocol described by Dhar et al. (2001), to confirm the correct extraction of DNA from the samples and discard inhibitions. In the second PCR a segment of the VP41B gene of WSSV was amplified following the protocol described by Dhar et al. (2001), and in the third PCR a segment of the SSU rRNA gene of EHP was amplified according to the protocol described by Tang et al. (2015). The reaction mixture for the PCR included DNA template (0.8-1.6 $\mu \mathrm{M}$ ), primers at $10 \mu \mathrm{M}$ concentration, and 0.6 $\mu \mathrm{M}$ Master Mix (DreamTaq, Thermofisher®), for a final volume of $25 \mu \mathrm{l}$. DNA from WSSV and EHP, acquired from the University of Arizona, USA, was used as positive control. Nuclease-free water (Fermentas $\left.{ }^{\circledR}\right)$ was used as negative control.

Table 1. Primers sequences, amplification protocols, and PCRs references used to detect the $\beta$-actin gene, WSSV, and EHP.

Cuadro 1. Secuencias de los cebadores, protocolos de amplificación y referencias de los PCRs utilizados para detectar el gen $\beta$-actina, WSSV y EHP.

\begin{tabular}{|c|c|c|c|c|c|}
\hline Gene & Primers & Sequences & $\begin{array}{l}\text { Product } \\
\text { size (bp) }\end{array}$ & Amplification protocol & Reference \\
\hline \multirow[b]{2}{*}{$\beta$-actin } & Actin-F & CCCAGAGCAAGAGAGGTA & \multirow[b]{2}{*}{339} & \multirow{2}{*}{$\begin{array}{l}10 \text { min of initial denaturation at } 95{ }^{\circ} \mathrm{C} \text {, } \\
35 \text { cycles of denaturation }\left(95{ }^{\circ} \mathrm{C} \text { for }\right. \\
45 \mathrm{~s}) \text {, alignment }\left(55^{\circ} \mathrm{C} \text { for } 1 \mathrm{~min}\right) \text { and } \\
\text { extension }\left(72{ }^{\circ} \mathrm{C} \text { for } 2 \mathrm{~min}\right) \text {, and final } \\
\text { extension of } 72{ }^{\circ} \mathrm{C} \text { for } 7 \mathrm{~min}\end{array}$} & \multirow{2}{*}{$\begin{array}{c}\text { Dhar et al. } \\
\quad(2001)\end{array}$} \\
\hline & Actin-R3 & GCGTATCCTTCGTAGATGGG & & & \\
\hline \multirow[b]{2}{*}{ WSSV } & F002 & GATGAGACAGCCCAAGTTGTTAAAC & \multirow[b]{2}{*}{306} & \multirow{2}{*}{$\begin{array}{l}10 \text { min of initial denaturation at } 95{ }^{\circ} \mathrm{C} \text {, } \\
35 \text { cycles of denaturation }\left(95{ }^{\circ} \mathrm{C} \text { for }\right. \\
45 \mathrm{~s}) \text {, alignment }\left(55^{\circ} \mathrm{C} \text { for } 1 \mathrm{~min}\right) \text { and } \\
\text { extension }\left(72{ }^{\circ} \mathrm{C} \text { for } 2 \mathrm{~min}\right) \text {, and final } \\
\text { extension temperature of } 72{ }^{\circ} \mathrm{C} \text { for } 7 \mathrm{~min} .\end{array}$} & \multirow{2}{*}{$\begin{array}{c}\text { Dhar et al. } \\
\text { (2001) }\end{array}$} \\
\hline & R002 & CGAAATTCCATCACTGTAATTGCTTG & & & \\
\hline \multirow[t]{2}{*}{ EHP } & EHP-510F & GCCTGAGAGATGGCTCCCACGT & \multirow[t]{2}{*}{500} & $\begin{array}{l}3 \text { min of initial denaturation at } 94{ }^{\circ} \mathrm{C} \text {, } \\
35 \text { cycles of denaturation }\left(94{ }^{\circ} \mathrm{C} \text { for } 30\right.\end{array}$ & \multirow{2}{*}{$\begin{array}{l}\text { Tang et al. } \\
\quad(2015)\end{array}$} \\
\hline & EHP-510R & GCGTACTATCCCCAGAGCCCGA & & extension temperature of $72^{\circ} \mathrm{C}$ for $5 \mathrm{~min}$ & \\
\hline
\end{tabular}

The PCR products were visualized using agarose gel electrophoresis $(1 \%)$ in TBE $1 \mathrm{X}$ (Tris base, boric acid, EDTA, pH 8,0.5M). The electrophoretic run was performed at 100 volts for 45 min. GeneRuler 100 bp DNA Ladder Plus (Fermentas ${ }^{\circledR}$ ) was used as a molecular weight marker, and GelRed® Nucleic Acid Gel Stain dye was used as a colorant. Amplification fragments with a size of $306 \mathrm{bp}$ (WSSV) and $500 \mathrm{bp}$ (EHP) were considered positive and all but those of actin were sent to Macrogen (Seoul, Korea) to be sequenced. The partial sequence was aligned with the BioEdit Sequence Aligment Editor ${ }^{\circledR}$ program and compared using the BLASTn algorithm (Joshi et al., 2014 using the National Center for Biotechnology Information (NCBI) database. The sequences obtained were deposited in the GenBank. 


\section{Statistical analysis}

The results of the surveys and the results of the PCR of WSSV and EHP were entered into a database, and a descriptive analysis of the positive farms was carried out. A map was created with the QGIS 2.14.0 program to show the distribution of the shrimp farms analyzed, and positive cases were identified.

\section{Results}

The PCR protocols implemented to amplify segments of the WSSV and EHP genes are shown in the Figure 1. The amplifications yielded better results when DNA extractions were used without dilution or in 1/10 dilution.
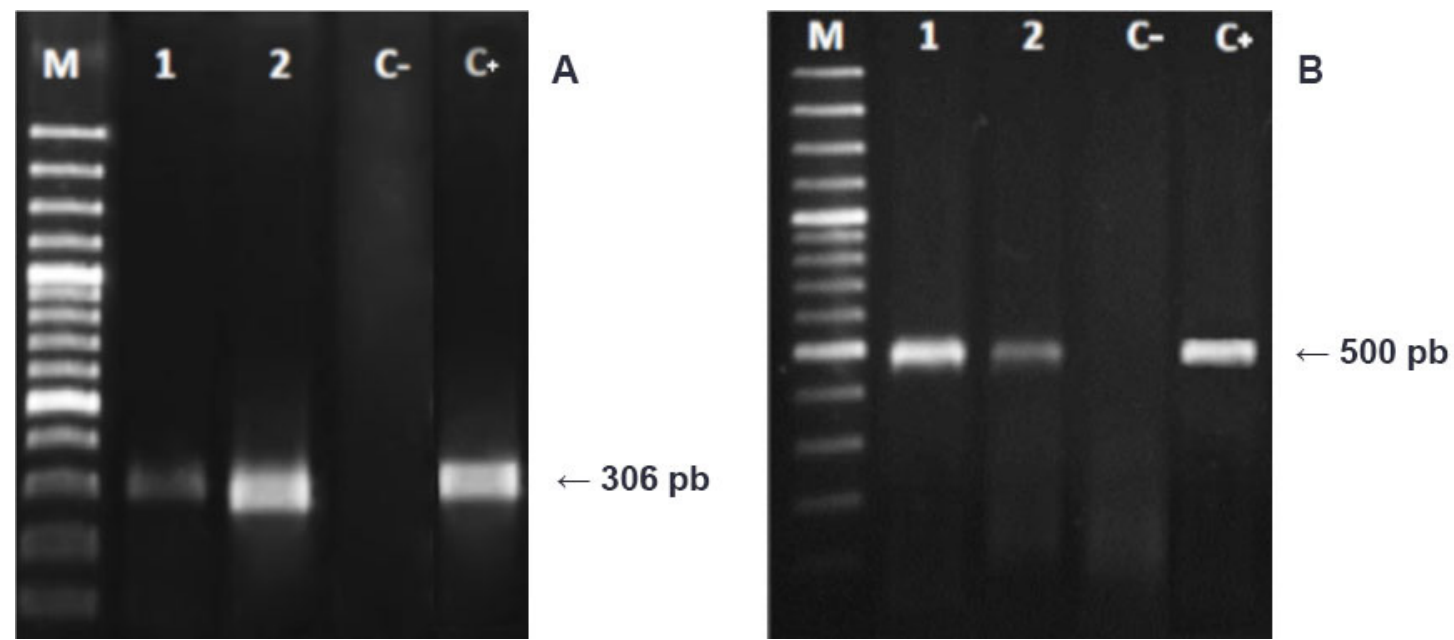

Figure 1. Agarose gel electrophoresis showing the PCR products of the implemented protocols for amplification of white spot syndrome virus (WSSV) (A) and Enterocytozoon hepatopenaei (EHP) (B). Costa Rica, 2017-2018.

1A: M: $100 \mathrm{~kb}$ molecular weight marker. 1: positive hepatopancreas of shrimp from Costa Rica, undiluted; 2: positive shrimp hepatopancreas from Costa Rica 1/10 dilution; C-: negative control, C+: positive WSSV control, undiluted. 1B: M: $100 \mathrm{~kb}$ molecular weight marker. 1: positive EHP control, undiluted; 2: positive EHP control, 1/10 dilution; C-: negative control, C+: positive EHP control, undiluted.

Figura 1. Electroforesis en gel de agarosa que muestra los productos de PCR de los protocolos implementados para el virus del síndrome de la mancha blanca (WSSV) (A) y de Enterocytozoon hepatopenaei (EHP) (B). Costa Rica, 2017-2018.

1A: M: marcador de peso molecular de $100 \mathrm{~kb}$. 1: hepatopáncreas de camarón positivo de Costa Rica, sin diluir; 2: hepatopáncreas de camarón positivo de Costa Rica, dilución 1/10; C-: control negativo, C+: control positivo de WSSV, sin diluir. 1B: M: marcador de peso molecular de $100 \mathrm{~kb}$. 1: control positivo EHP, sin diluir; 2: control positivo EHP, dilución 1/10; C-: control negativo, C+: control positivo de EHP, sin diluir.

All postlarvae, and juvenile shrimp stomachs and hepatopancreas from all farms amplified the internal actin control using PCR. The water samples (supernatant and sediment) that were obtained during the filling process of the pond in the every farms were negative for WSSV and EHP, as were the postlarvae and juvenile shrimp stomachs. Only the hepatopancreas of the shrimp collected from the middle of the pond of farm 9 were positive for WSSV, while the remaining hepatopancreas from the other farms were negative for WSSV and EHP (Figure 2). 


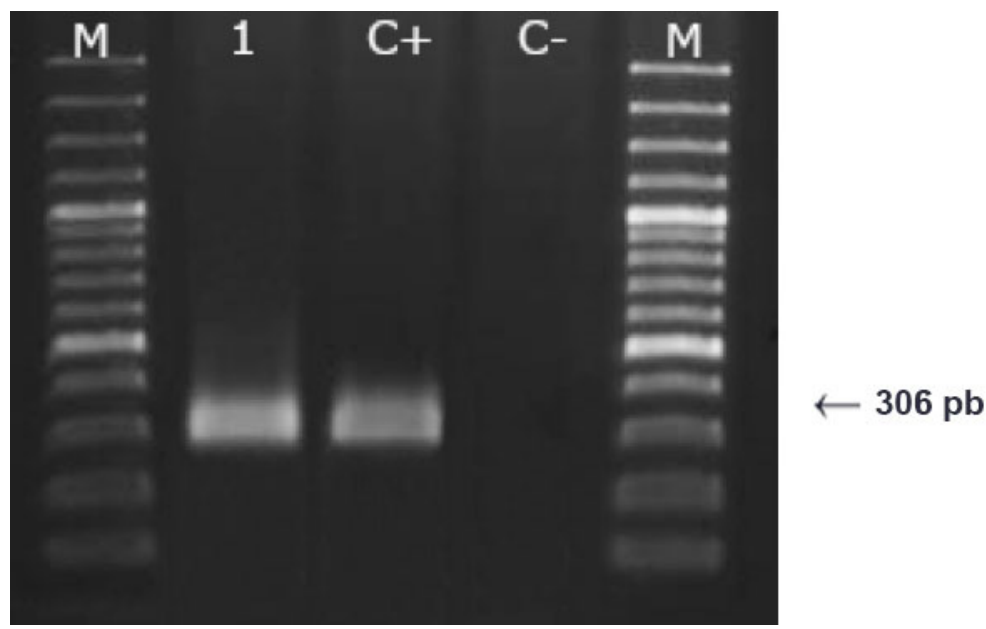

Figure 2. Agarose gel electrophoresis showing the amplified PCR products of juvenile shrimp (Penaeus vannamei), obtained from one farm located in the Gulf of Nicoya, showing the presence of white spot syndrome virus (WSSV). Costa Rica. 2017-2018.

M: $100 \mathrm{~kb}$ molecular weight marker. Line 1: positive shrimp hepatopancreas from Costa Rica; C+: positive control; C-: negative control.

Figura 2. Electroforesis en gel de agarosa que muestra los productos de PCR amplificados de camarones juveniles (Penaeus vannamei), obtenidos de una granja ubicada en el Golfo de Nicoya, que muestra la presencia del virus del síndrome de la mancha blanca (WSSV). Costa Rica. 2017-2018.

M: marcador de peso molecular de 100 kb. 1: hepatopáncreas de camarón positivo de Costa Rica; C+: control positivo; C-: control negativo.

The sequence obtained for the VP41B gene of WSSV in Farm 9 was identical (100 \%, 306pb/306pb) to sequences isolated form shrimp from Taiwan (AF440570.1) and Mexico (KU216744.2) (Figure 3), this sequence was deposited in the GenBank database with access number MH553567.

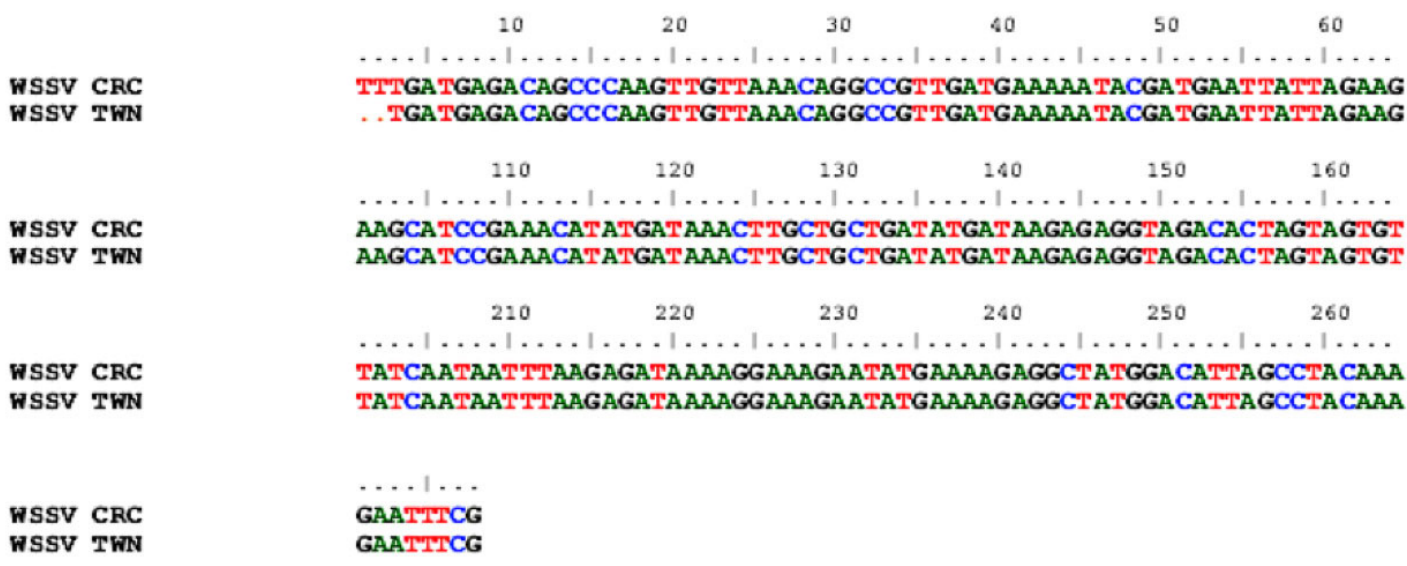

Figure 3. Alignment of the sequence of the white spot syndrome virus (WSSV) isolated from a hepatopancreas shrimp from Costa Rica (WSSV CRC) in shrimp (Penaeus vannamei) from one farm located in the Gulf of Nicoya, and the WSSV sequence isolated from a shrimp from Taiwan (WSSV TWN), based on the ClustalW2 program, and deposited in the GenBank. 2018.

Figura 3. Alineación de la secuencia del virus del síndrome de la mancha blanca (WSSV) aislado de un hepatopáncreas de camarón de Costa Rica (WSSV CRC), en camarones (Penaeus vannamei) de una granja ubicadas en el Golfo de Nicoya, con la secuencia de WSSV aislada de un camarón de Taiwán (WSSV TWN), con base en el programa ClustalW2 y depositadas en el GenBank. 2018. 
The positive WSSV farm (Farm 9) was located in the canton of Abangares (Figure 4) with a pond smaller than 2 ha in size. At the time of the sampling (November 2017), the positive farm showed the following water quality parameters: $3 \mathrm{mg} \mathrm{l}^{-1}$ of dissolved oxygen, temperature of $34.5^{\circ} \mathrm{C}$, $\mathrm{pH}$ of 8.24 , and salinity of $22.39 \mathrm{ppt}$. A density of 10 postlarvae per $\mathrm{m}^{2}$ were stocked in this farm, and the production cycle took less than four months. Water quality was not monitored, nor were production records maintained. In previous cycles the farm had experienced problems associated with WSSV, mainly mortality, and SENASA confirmed the presence of WSSV through conventional PCR.

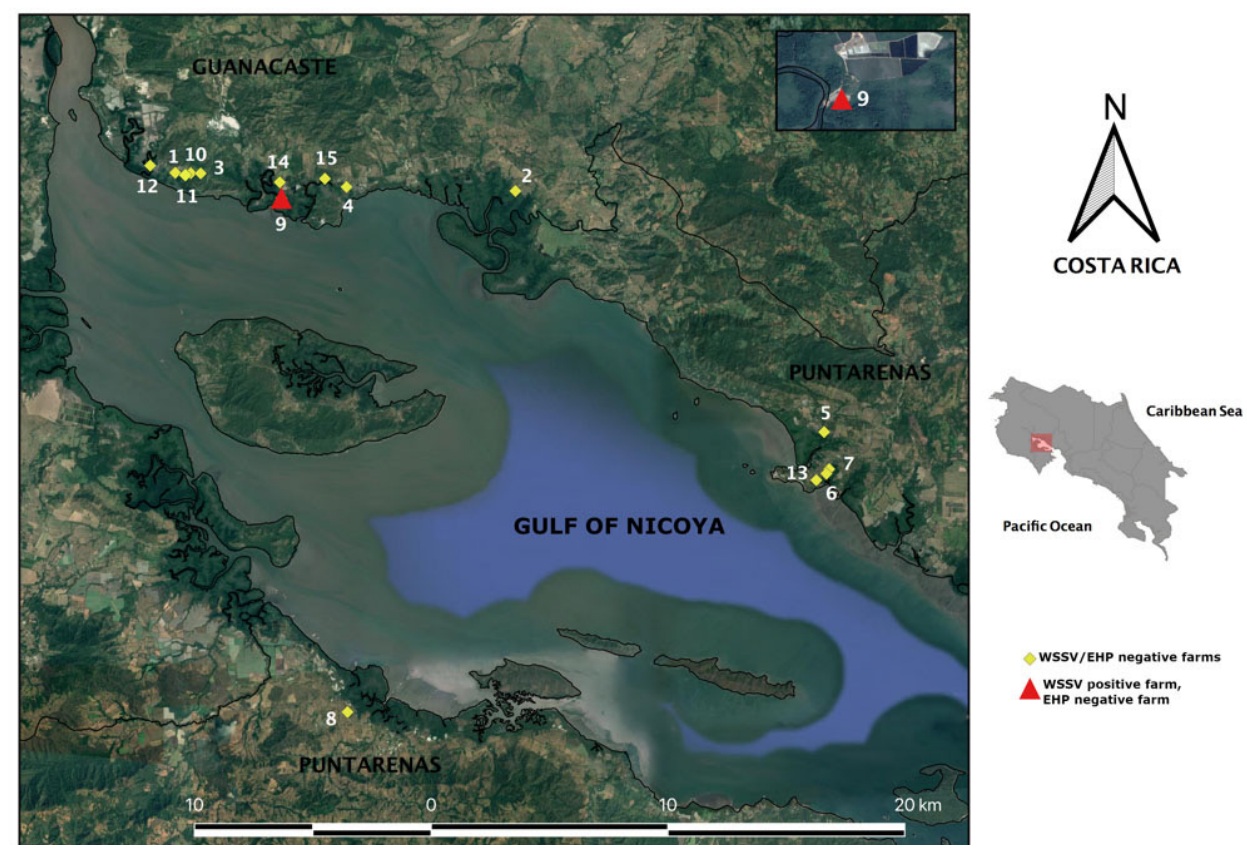

Figure 4. Geographical distribution of the productive shrimp farms analyzed for white spot syndrome virus (WSSV) and Enterocytozoon hepatopenaei (EHP) in the Gulf of Nicoya and Central Pacific from Costa Rica between January 2017 and July 2018, and location of the WSSV positive farm (Inset shows enlarged area of the positive farm).

Figura 4. Distribución geográfica de las fincas camaroneras productivas analizadas para el virus del síndrome de la mancha blanca (WSSV) y Enterocytozoon hepatopenaei (EHP), en el Golfo de Nicoya y el Pacífico Central de Costa Rica entre enero 2017 y julio 2018, y ubicación de la finca positiva para WSSV (El recuadro muestra el área ampliada de la granja positiva).

\section{Discussion}

Presence of the white spot syndrome virus was detected in one $(6.7 \%)$ of the fifteen farms analyzed. This finding is consistent with the fact that WSSV is considered endemic in Costa Rica and agrees with SENASA records of cases of WSSV over time (SENASA, 2017). However, a low presence was found, contrary to that reported by Morales et al. (2011), who found prevalence's of 15-100 \% between 2008 and 2009, and by Varela and Peña (2013), who reported 45 cases between 2012 and 2013 in Costa Rica. In contrast, another study conducted in three shrimp producing farms in the same region during 2013-2014 found no WSSV present using histology and PCR (Peña and Varela, 2016). The differences in the findings could be due to the types of studies (cross-sectional or case studies), or to the molecular techniques used. In some cases, nested PCR can yield false negative results for farms with a 
low viral load, which makes it recommendable to use more sensitive techniques such as real-time PCR (Dhar et al., 2001).

Presence of the virus in Costa Rica can also be influenced by environmental factors such as temperature, the shrimp physiological condition and susceptibility, as well as viral load. It has been reported that the WSSV develops rapidly at temperatures close to $25^{\circ} \mathrm{C}$, and virus replication stops under conditions of hyperthermia (32 ${ }^{\circ} \mathrm{C}$ ), explaining why outbreaks occur more frequently during times when water temperature is lower (Vidal et al., 2001; Granja et al., 2003; Lightner, 2011). The type of study carried out in the present work (cross-sectional) did not allow determining temperatures during the productive cycle, and it is recommended to carry out longitudinal studies that investigate environmental factors that favor increased expression of the virus (Vázquez et al., 2016).

The sequence of the VP41B gene of WSSV amplified in the present work was similar to the sequence detected in shrimp of Penaeus monodon in Taiwan (Tsai et al., 2000) and Penaeus vannamei in Mexico (Rodríguez-Araya et al., 2016). The complete WSSV genome has been sequenced in different parts of the world, detecting deletions in the envelope and capsid proteins which modify the way in which the virus interacts with its host in terms of its recognition by the host cell and the immune system, reducing its capacity to cause mortality (Restrepo et al., 2018). For this reason, it is recommended to determine the complete genome sequence of the viral strain in Costa Rica, to establish if it has variations in its structural proteins.

Given that WSSV is a notifiable disease in Costa Rica, a positive pond should be isolated, and, in cases of high animal mortality, production should be eliminated, and sanitary measures implemented (SENASA, 2005). It is also recommended to carry out a total drying of the pond during the dry season and to eliminate mollusks, copepods and other crustaceans (Cuéllar-Anjel et al., 2014). The implementation of biosecurity measures (disinfection of the pond with sodium hypochlorite, lime, detergents or organic compounds) seem to be the only alternative to reduce the risk of entry and permanence of WSSV in shrimp farms (Lightner, 2005). In Costa Rica, however, if the sizes of these shrimp are sufficient, they are sold to reduce economic losses to producers (Cuéllar-Anjel, 2013). A limitation of the present study was that the amount of production harvested was not determined, and therefore it was not possible to establish the effect of the pathogen on mortality and feed conversion rate.

There were no positive results for EHP found during this investigation; however, it is necessary to increase biosafety measures in order to reduce the possibility of entry of this infectious agent into the country. In Latin America, the presence of EHP has been confirmed in Venezuela (Tang et al., 2017b), and it is possible that this pathogen may appear in other countries of the region.

\section{Conclusions}

In the present study, a very low frequency of WSSV and no EHP was found in the farms, using molecular techniques. It is recommended, to continue monitoring these agents in shrimp farms of Costa Rica.

\section{Acknowledgments}

The authors acknowledge to the Fondo Institucional de Desarrollo Academico (FIDA) and the Vicerrectoria de Investigacion of the Universidad Nacional de Costa Rica for the proyects' financing. Thanks also to the Universidad Tecnica Nacional (UTN) and the Ministerio de Ciencia, Tecnologia y Comunicaciones (MICITT) for their financial support and the grant awarded to Nelson Peña to pursue a Masters' Degree in Tropical Diseases. 


\section{Conflict of interest and ethical declaration}

The authors declare no conflict of interest. The institutions involved in the research do not have an ethics committee; the country does not request one. However, the necessary measures were taken to manage the welfare of the animals used.

\section{Cited literature}

Aranguren, L.F., J.E. Han, and K.F.J. Tang. 2017. Enterocytozoon hepatopenaei (EHP) is a risk factor for acute hepatopancreatic necrosis disease (AHPND) and septic hepatopancreatic necrosis (SHPN) in the Pacific white shrimp Penaeus vannamei. Aquaculture 471:37-42. doi:10.1016/j.aquaculture. 2016.12.038

Bustillo, M., C. Escobedo, y R. Sotelo. 2009. Revisión de patogénesis y estrategias moleculares contra el virus del síndrome de la mancha blanca en camarones peneidos. Rev. Biol. Marina Oceanogr. 44(1):1-11. doi:10.4067/S0718-19572009000100001

Cardona, E., Y. Gueguen, K. Magré, B. Lorgeoux, D. Piquemal, F. Pierrat, F. Noguier, and D. Saunier. 2016. Bacterial community characterization of water and intestine of the shrimp Litopenaeus stylirostris in a biofloc system. BMC Microbiol. 16:157. doi:10.1186/s12866-016-0770-z

Crockford, M. 2008. White spot disease. Australia and New Zealand standard diagnostic procedures. Australian Government, AUS. https://www.agriculture.gov.au/sites/default/files/sitecollectiondocuments/animal/ahl/ANZSDP-White-spotsyndrome-virus.pdf (accessed Sep. 25, 2018).

Cuéllar-Anjel, J. 2013. Enfermedad de las manchas blancas. The Center for Food Security \& Public Health, IA, USA.

Cuéllar-Anjel, J., V. Morales, C. Lara, y O. García. 2014. Buenas prácticas y bioseguridad para el cultivo del camarón blanco Penaeus (Litopenaeus) vannamei (Boone, 1931). En: V. Morales, y J. Cuéllar-Anjel, editores, Patología e inmunología de camarones penaeidos. Guía técnica. CYTED, PAN. p. 225-242.

Dhar, A.K., M.M. Roux, and K.R. Klimpel. 2001. Detection and quantification of infectious hypodermal and hematopoietic necrosis virus (IHHNV) and white spot virus (WSV) of shrimp by real-time quantitative PCR and SYBR chemistry. J. Clinical Microbiol. 39:2835-2845. doi:10.1128/ JCM.39.8.2835-2845.2001

Granja, C.B., L.F. Aranguren, O.M. Vidal, L. Aragon, and M. Salazar. 2003. Does hyperthermia increase apoptosis in white spot syndrome virus (WSSV)-infected Litopenaeus vannamei. DAO 54:73-78. doi:10.3354/dao054073

Haq, M.A.B, R. Vignesh, and M. Srinivasan. 2012. Deep insight into white spot syndrome virus vaccines: A review. Asian Pacific J. Trop. Dis. 2:73-77. doi:10.1016/S2222-1808(12)60018-8

Jaroenlak, P., P. Sanguanrut, B.A.P. Williams, G.D. Stentiford, T.W. Flegel, K. Sritunyalucksana, and O. Itsathitphaisarn. 2016. A nested PCR assay to avoid false positive detection of the microsporidian Enterocytozoon hepatopenaei (EHP) in environmental samples in shrimp farms. PLoS ONE 11(11):e0166320. doi:10.1371/journal.pone.0166320

Joshi, J., J. Srisala, Y.H. Truong, I.T. Chen, B. Nuangsaeng, O. Suthienkul, C.F. Lo, T.W. Flegel, K. Sritunyalucksana, and S. Thitamadee. 2014. Variation in Vibrio parahaemolyticus isolates from a single Thai shrimp farm experiencing an outbreak of acute hepatopancreatic necrosis disease (AHPND). Aquaculture 428-429:297-302. doi:10.1016/j. aquaculture.2014.03.030

Lightner, D.V. 2005. Biosecurity in shrimp farming: Pathogen exclusion through use of SPF stock and routine surveillance. J. World Aqua. Soc. 36:229-248. doi:10.1111/j.1749-7345.2005.tb00328.x 
Lightner, D.V. 2011. Virus diseases of farmed shrimp in the Western Hemisphere (the Americas): A review. J. Invert. Pathol. 106:110-130. doi:10.1016/j.jip.2010.09.012

Lo, C.F., T. Aoki, J.R. Bonami, T.W. Flegel, J.H. Leu, D.V. Lightner, G. Stentiford, K. Söderhäll, P.W. Walker, H.C. Wang, X. Xun, F. Yang, and J.M. Vlak. 2012. Nimaviridae. In: A.M.Q. King et al., editors, Virus taxonomy: Classification and nomenclature of viruses: Ninth report of the international committee on taxonomy of viruses. Elsevier Academic Press, San Diego, CA, USA. p. 229-234.

Morales, M.S., A. Ruiz, A. Pereira, V.T. Solís, y G. Conroy. 2011. Prevalencia de enfermedades de camarón blanco (Litopenaeus vannamei) cultivados en ocho regiones de Latinoamérica. Rev. FCV-LUZ 21:434-446.

OIE. 2018. White spot disease. Manual of diagnostic test for aquatic animals. Chapter 2.2.5. OIE, Paris, FRA. http://www.oie. int/fileadmin/Home/eng/Health_standards/aahm/2009/2.2.05_WSD.pdf (accessed Oct. 29, 2018).

Peña, N., y A. Varela. 2016. Prevalencia de las principales enfermedades infecciosas en el camarón blanco Penaeus vannamei cultivado en el Golfo de Nicoya, Costa Rica. Rev. Biol. Marina Oceanogr. 51:553-564. doi:10.4067/S071819572016000300007

Rajendran, K.V., S. Shivam, P.E. Praveena, J.J. Sahaya, T.S. Kumar, S.Avunje, V. Jagadeesan, S.V.A.N.V. Prasad-Babu, A. Pande, A. Navaneeth-Krishnan, S.A. Alavandi, and K.K. Vijayan. 2016. Emergence of Enterocytozoon hepatopenaei (EHP) in farmed Penaeus (Litopenaeus) vannamei in India. Aquaculture 454:272-280. doi:10.1016/j.aquaculture.2015.12.034

Restrepo, L., A. Reyes, L. Bajaña, I. Betancourt, and B. Bayot. 2018. Draft genome sequence of a White Spot Syndrome Virus isolate obtained in Ecuador. Genome Announ. 6(26):e00605-18. doi.org/10.1128/genomeA.00605-18

Rodríguez-Anaya, L.Z., J.R. González-Galaviz, R. Casillas-Hernández, F. Lares-Villa, K. Estrada, J.C. Ibarra-Gámez, and A. Sánchez-Flores. 2016. Draft genome sequence of white spot syndrome virus isolated from cultured Litopenaeus vannamei in México. Genome Announc. 4(2):e01674-15. doi:10.1128/genomeA.01674-15

Sánchez-Paz, A. 2010. White spot syndrome virus: an overview on an emergent concern: Review article. Vet. Res. $41(6): 43$. doi: $10.1051 /$ vetres/2010015

SENASA (Servicio Nacional de Sanidad Animal). 2005. Manual de buenas prácticas pecuarias en acuicultura. SENASA, Heredia, CRI. http://www.senasa.go.cr/senasa/sitio/files/121211080451.pdf (consultado 29 oct. 2018).

SENASA (Servicio Nacional de Sanidad Animal). 2010. Protocolo de vigilancia epidemiológica para la enfermedad de las Manchas Blancas. Programa nacional sanidad acuícola. SENASA, Heredia, CRI. http://www.senasa.go.cr/senasa/sitio/ files/141211080925.doc (consultado 25 set. 2018).

SENASA (Servicio Nacional de Sanidad Animal). 2017. Informe OIE WAHID. SENASA, Heredia, CRI. http://www.senasa. go.cr/senasa/informacion/centro-de-informacion/informacion/estado-sanitario/oie/informes-organización-mundial-desanidad-animal-oie (consultado 13 ene. 2018).

Shen, H., G. Jiang, X. Wan, X. Fan, Y. Qiao, W. Shi, H. Li, and L. Wang. 2017. Multiple pathogens prevalent in shrimp Penaeus vannamei cultured from greenhouse ponds in Jiangsu Province of China. J. Aquac. Res. Dev. 8:10. doi:10.4172/21559546.1000516

Tang, K., F. Aranguren, J.E. Han, I. Maskaykina, M. Schmidt, and D. Lightner. 2017a. Histopathology and in situ detection of the microsporidian Enterocytozoon hepatopenaei (EHP) in Penaeus vannamei cultured in a Latin America country. World Aquaculture Society, USA. https://www.was.org/meetings/ShowAbstract.aspx?Id=46059 (accessed Mar. 15, 2019).

Tang, K., F. Aranguren, P. Piansomboon, J.E. Han, I. Maskaykina, and M. Schmidt. 2017b. Detection of the microsporidian Enterocytozoon hepatopenaei (EHP) and Taura syndrome virus in Penaeus vannamei cultured in Venezuela. Aquaculture 480:17-21. doi:10.1016/j.aquaculture.2017.07.043 
Tang, K.F.J., J.E. Han, L.F. Aranguren, B. White-Noble, M.M. Schmidt, P. Piamsomboon, and B. Hanggono. 2017c. Dense populations of the microsporidian Enterocytozoon hepatopenaei (EHP) in feces of Penaeus vannamei exhibiting white feces syndrome and pathways of their transmission to healthy shrimp. J. Invertebr. Pathol. 140:1-7. doi:10.1016/j. jip.2016.08.004

Tang, K.F.J., C.R. Pantoja, R.M. Redman, J.E. Han, L.H. Tran, and D.V. Lightner. 2015. Development of in situ hybridization and PCR assays for the detection of Enterocytozoon hepatopenaei (EHP), a microsporidian parasite infecting penaeid shrimp. J. Invertebr. Pathol. 130:37-41. doi:10.1016/j.jip.2015.06.009

Tangprasittipap, A., J. Srisala, S. Chouwdee, M. Somboon, N. Chuchird, C. Limsuwan, T. Srisuvan, T.W. Flegel, and K. Sritunyalucksana. 2013. The microsporidian Enterocytozoon hepatopenaei is not the cause of white feces syndrome in whiteleg shrimp Penaeus (Litopenaeus) vannamei. BMC Vet. Res. 9:139. doi:10.1186/1746-6148-9-139

Tourtip, S., S. Wongtripop, G.D. Stentiford, K.S. Bateman, S. Sriurairatana, J. Chavadej, K. Sritunyalucksana, and B. Withyachumnarnkul. 2009. Enterocytozoon hepatopenaei sp. nov. (Microsporida: Enterocytozoonidae), a parasite of the black tiger shrimp Penaeus monodon (Decapoda: Penaeidae): Fine structure and phylogenetic relationships. J. Invertebr. Pathol. 102:21-29. doi:10.1016/j.jip.2009.06.004

Tsai, M.F., C.F. Lo, M.C.W. van-Hulten, H.F. Tzeng, C.M. Chou, C.J. Huang, C.H. Wang, J.Y. Lin, J.M. Vlak, and G.H. Kou. 2000. Transcriptional analysis of the ribonucleotide reductase genes of shrimp white spot syndrome virus. Virology 277:92-99. doi:10.1006/viro.2000.0596

Varela, A., y N. Peña. 2013. El virus del Síndrome de las Manchas Blancas (WSSV): una revisión y su impacto en la camaronicultura costarricense. Rev. Cienc. Vet. 28(2):51-69.

Vásquez-Sauceda, M.L., J.G. Sánchez-Martínez, R. Pérez-Castañeda, J.L. Rábago-Castro, G. Aguirre-Guzmán, and D.Y. VargasCruz. 2016. White Spot Syndrome Virus (WSSV) and Necrotizing Hepatopancreatitis (NHP) detection in wild shrimp of the San Andrés Lagoon, Mexico. Rev. Biol. Mar. Oceanogr. 51:455-459. doi:10.4067/S0718-19572016000200023

Vidal, O.M., C.B. Granja, F. Aranguren, J.A. Brock, and M. Salazar. 2001. A profound effect of hyperthermia on survival of Litopenaeus vannamei juveniles infected with White spot syndrome virus. J. World Aquac. Soc. 32:364-372. doi:10.1111/j.1749-7345.2001.tb00462.x

Wu, J.L., A. Namikoshi, T. Nishizawa, K. Mushiake, K. Teruya, and K. Muroga. 2001. Effects of shrimp density on transmission of penaeid acute viremia in Penaeus japonicus by cannibalism and the waterborne route. Dis. Aquatic Organ. 47:129-135. doi:10.3354/dao047129 